\title{
Study of some Alluvial soil's sediments characteristics in Toshka Depression, Egypt.
}

\author{
Mohammed M. Sherif \\ Director of Water Studies and Research complex Toshka, Abu Simbel City, National Water \\ Research Center, Egypt.
}

\section{ABSTRACT}

Egypt is one of the most populous countries in Africa and the Middle East. Toshka Depression (TD), are located to the west of Lake Nasser, in the western desert of Egypt they consist of four deep-cut basins connected by naturally and far away about $250 \mathrm{~km}$ south of Aswan. Alluvium Operation is estimated that on the average of 133.54 million tons enter the high dam reservoir each year. About $97 \%$ of this amount precipitates in the reservoir and 3\% is carried through Aswan High dam.

The main target of this work is to study some Alluvial soil's sediments characteristics for expansion in agricultural area by optimum exploitation for investment some of shoreline of soils in Toshka Depression, or for possible use in land reclamation in Toshka area. The results of physical and chemical soil properties varied from layer to layer and were recorded as silt clay loam, clay loam, clay and silt loam. Soil reaction "soil $\mathrm{pH}$ " values were moderate and increased with depth. Electrical Conductivity (EC) of the alluvial soils in Toshka Depression are classified under soil salinity class "slightly saline soils". Gypsum distribution followed a regular pattern from the surface layer to subsurface ones. However, gypsum accumulates at the end of soil profile at depth of $120-125 \mathrm{~cm}$. The highest value of Calcium carbonate $\left(\mathrm{CaCO}_{3} \%\right)$ content was observed in the surface layer and sharply decreased in the subsurface layer with irregular distribution with soil depth. Organic matter (OM) content at surface layer of alluvial sediment soils was very reach. Cation Exchange Capacity (CEC) increased with higher clay content in subsurface layer. Exchangeable sodium percentage (ESP) values of the studied soils are less than the critical value and consider moderately suitable $\left(\mathrm{S}_{2}\right)$. Alluvial subsurface soil sediment suffers from a sever lack of available macronutrients NPK. Data revealed that the most concentration of total and available heavy metals were observed in surface layer of alluvial soil sediment profile at Toshka Depression. X-ray diffraction patterns obtained for the bulk alluvial soil sediments indicated the presence of Illite, Vermiculite, Montmorillonite, Kaolinite-1A, Magnetite, Hematite, Berlinite, Cronstedtite-1T, Cuprite, Fraipontite-1O, Calcite, Gypsum, Bustamite, Wollastonite-1A, and Brushite are much more abundant. All these minerals are very important for land reclamation in Toshka area.

Keywords: Alluvial soils, sediments, X-ray diffraction, Toshka Depression, Lake Nasser, chemical properties.

\section{INTRODUCTION}

Toshka Depression (TD) is a massive $6000 \mathrm{~km}^{2}$ of relatively low land. This domain comprises five unnamed lakes and several shallow spots at elevation below water level of Lake Nasser. The area of those low level spots exceeds 150,000 acres and can be developed, for agricultural production; seasonal crops and live stocks. 
Toshka Depression, is located to the west of Lake Nasser, in the western desert of Egypt (Fig. 1). The composition of the sediment is about $30 \%$ fine sand, $40 \%$ silt and $30 \%$ clay with particle size less than $0.002 \mathrm{~mm}$. In addition, makes use of this valuable sediments to reclaim and develop new arable land in Egypt, as well, as protecting the Nile delta from flooding by the sea due to anticipated global warming. (Maher, 2012). Terrestrial sedimentation buries large amounts of organic carbon (OC) annually, OC content of sediments was approximately half of that in soils Fayos et al., 2015).

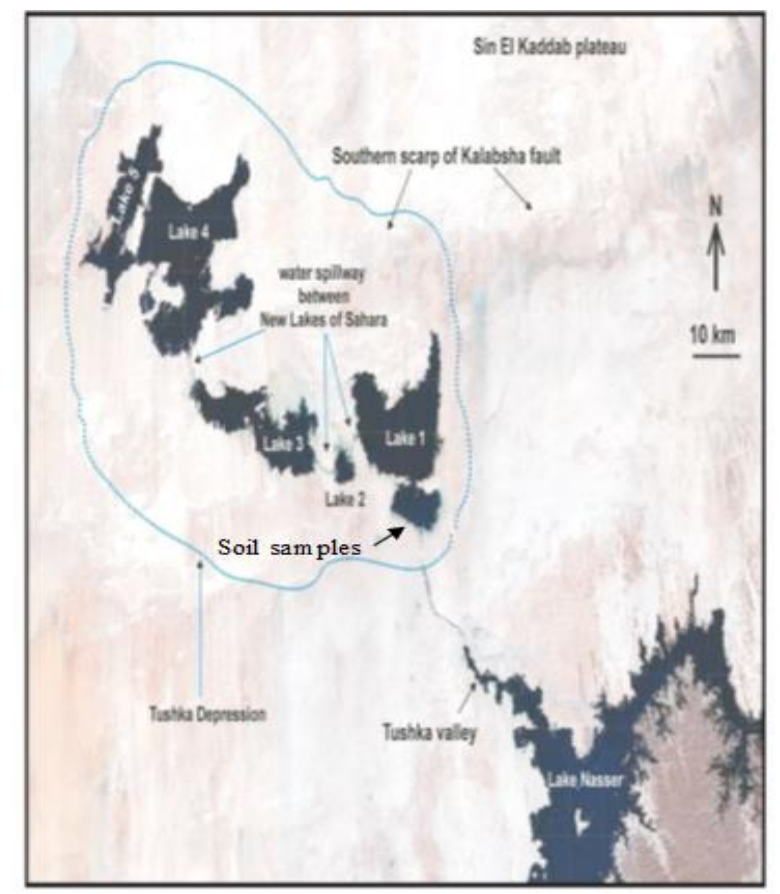

Fig. 1: Toshka Depression LANDSAT 7 Source Maher (2012) 12-2001

River sediments are basic component of our environment. In sediments of River Nile, the order of accumulation was $\mathrm{Fe}>\mathrm{Zn}>\mathrm{Mn}>\mathrm{Cu}>\mathrm{Ni}>\mathrm{Pb}>\mathrm{Cd}>\mathrm{Cr}>\mathrm{Hg}$ (Ibrahim and Omer, 2013). Yahia and Sebaee (2012) found that the order of heavy metal accumulation in sediment in Rosetta branch of River Nile was $\mathrm{Fe}>\mathrm{Zn}>\mathrm{Cu}>\mathrm{Pb}$ $>$ Cd. Awadallah et al., (1996) found that statistical analysis of data showed significant correlation coefficient values ( $\mathrm{r}=$ up to 0.915$)$ at study of relationship between heavy metals in mud sediments and beach soil of the River Nile between Aswan and Giza. Results showed that iron and lead were found at levels higher in beach soil than in the river sediments at all sites except for iron in sediments of Aswan where the region was subjected to volcanic activities in the ancient geological eras (granites, etc.) At some sites, heavy-metal concentration was higher in sediment than in beach soil samples due to weathering of beach soil by wind and water. Mohamed and Mostafa (2015) found that the concentration of zinc in sediment is ranged from 190.3 to $3036.8 \mathrm{mg}_{\mathrm{kg}} \mathrm{kg}^{-1}$, the highest value was detected in silt at El-Madiq in median part of lake, while the lowest at Saara in sand fraction. The data revealed that the highest of zinc found in silt and clay while the lowest is present in sand. The data revealed that the Mn was accumulated with clay fraction, while the cobalt accumulated in sand fraction. As well as, zinc and nickel ions were accumulated in silt fraction in Lake Nasser sediment. Sadik and Sawy (1980) and Hanna (2000) reported that the Alluvial soils of Nile valley and Delta could be classified as order Entisols and Vertisols; Vertisols defined as 
"Mineral soils that have 30\% or more clay, deep cracks when dry, and either (a natural) gilai micro relief, intersecting slickensides, or wedge shaped structural aggregates tilted at an angle from the horizontal. Hanna (2000) found that the abundant clay mineral in the Delta soils is montmorillonite (51\% of the clay fraction). Other identified portions are Kaolinite $(31 \%)$, Mica (11\%), Feldspars $(2 \%)$ and quartz (4\%). This clay is fine clay fraction causing large surface area for water absorption. One of the main soil physical characteristics of these soils is expansion by wetting and shrinking by drying. Also it was reported that the alluvial soils of the delta are stratified and heavy clay, which forms the majority, is alternated with heavy sandy or peaty horizons (Abdelhamid, 2013). The X-ray patterns of the clay mineralogy of the River Nile flood plain soils in Sohag region, showed that 2:1 clay minerals are much more abundant than kaolinite and this clay fraction contains fair amounts of $\mathrm{K}$-feldspar and quartz. XRD patterns obtained on the $<2 \mu \mathrm{m}$ fraction of the River Nile sediments indicating the presence of smectite, mixed-layer illite-expanding minerals, kaolinite, mica-illite and chlorite. Melegy and El-Agami (2004) stated that the Nile alluvial soils are composed mainly of montmorillonite ranges in abundance from $27 \%$ to $35 \%$, Kaolinite ranges from 29\%35.5\% and illite from 3\% to 11\%. Abu Seif and El-Shater (2010) identified five types of clay minerals namely smectite and kaolinite, mixed layer (smectite-kaolinite), chlorite and illite dominating the sediments. Carbonaceous sediments are derived from the accumulation of organic matter in lacustrine basins. Lacustrine organic matter may derive from organisms inhabiting the lake (cyanobacterial mats, macro- and microphytes, phytoplankton, zooplankton, benthic organisms or feces from aquatic or terrestrial organisms (Kelts, 1988; Essa and Farragallah, 2006). X-ray diffraction analysis of the clay fraction of the different irrigated soil samples at Assiut city, revealed that smectites occurred as major clay minerals in all studied soil samples, and tended to increase with depth. Kaolinite was the second abundant clay mineral, followed by mica-smectite mixed layers, vermiculite, mica-vermiculite mixed layers, mica, sepiolite and palygorskite that are arranged in a decreasing order of abundance. The source of these clay minerals in the studied soils is largely due to the detrital materials from the Ethiopian Plateau that is mixed with the detrital materials from the sandstones and limestones plateaus surrounding the River Nile course. Concerning the interaction between clay minerals and heavy metals, the significant relations between smectite and $\mathrm{Fe}$ or $\mathrm{Cu}$, kaolinite and $\mathrm{Pb}$, mica-smectite mixed layers and $\mathrm{Mn}$, mica-vermiculite mixed layers and $\mathrm{Zn}, \mathrm{Cu}$ or $\mathrm{Ni}$, vermiculite and $\mathrm{Cu}$, sepiolite and $\mathrm{Fe}$ or $\mathrm{Pb}$, and palygorskite and $\mathrm{Mn}$ or $\mathrm{Cu}$ may be mainly attributed to the adsorption of these heavy metals on these clay minerals.

The objective of this work is to study some physical and chemical Alluvial soil's sediments characteristics for expanding agricultural land by optimum exploitation for investment some of soils in Toshka Depression, or for possible use Alluvial soil's sediments in land reclamation in Toshka area.

\section{MATERIALS AND METHODS}

\section{Soil analysis}

Five soil samples covering an area of 10,000 feddan were taken from alluvial soil sediment adjacent to Toshka Depression (TD) at Latitude $23^{\circ} 06 \mathrm{~N}$ and longitude $31^{\circ} 08$ East. at different depth $(0-5,5-30,30-75,75-120$ and 120-125)cm. and analyzed in the Central Laboratory for Environmental Quality Monitoring (CLEQM). The collected soil samples were air dried, crushed and sieved through a $2 \mathrm{~mm}$ sieve and stored in plastic bottles prior to the following physical and chemical analysis. 
The soil samples were analyzed mechanically using the pipette method, described by Baruch and Barthakur (1997). Soil chemical analysis was carried out as follows: Soil reaction (soil $\mathrm{pH}$ ) was determined in the soil suspension (1:2.5 soils) using $\mathrm{pH}$ meter; Calcium Carbonate content was measured volumetrically using Collin's Calcimeter; Organic matter content was determined by Walkly and Black method; Gypsum content was measured by precipitation with acetone. Total soluble salts were determined by measuring the electrical conductivity "EC" of soil extract. Sodium and Potassium were measured by Flamephotometer instrument Model Scherwid, Calcium and Magnesium were determined by titration with versenate (EDTA) using ammonium purpurate as an indicator for calcium, and Eriochrome black $\mathrm{T}$ as an indicator for calcium plus magnesium. Carbonate and bicarbonate were measured by titration with $\mathrm{HCl}$ using phenolphthalein as an indicator for the carbonate and methyl orange as an indicator for bicarbonate and Chlorides were measured using Mohre, s methods according to Page et al., (1982). Cation exchange capacity was determined according to Black, (1982). Available Nitrogen, Phosphor and Potassium,(NPK) were determined by microkjeldahel method (Klute, 1986).Total heavy metals ( $\mathrm{Ba}, \mathrm{Cr}, \mathrm{Co}, \mathrm{Ni}, \mathrm{Cu}, \mathrm{Fe}, \mathrm{Mn}$ and $\mathrm{Zn}$ ) were determined as follows; Soil samples were digested using microwave digestion techniques (Little Janet et al., 1991) in which $0.25 \mathrm{~g}$ of air-dry samples, while $1 \mathrm{~g}$ from each powdered samples was placed in Teflon Vessel and heated with $3 \mathrm{ml} \mathrm{HNO} 365 \%$ and $3 \mathrm{ml} \mathrm{HF} 40 \%$ for 30 minutes. This treatment takes place using MILEST ONE MIS-1200 MEGA microwave digestion system with MDR (Microwave digestion rotor) technology. This method has proved to be a satisfactory alternative to prove to conventional reflux extraction. Digested samples were measured for total major Cations and total heavy metals and the values recorded in mg. $\mathrm{kg}^{-1}$ dry weight microwave and conventional extraction techniques for the determination of metals in soil samples using Inductively Coupled Plasma-Optical Emission Spectroscopy (ICP-OES) with ultrasonic Nebulizer (USN). Available $\mathrm{P}, \mathrm{K}, \mathrm{Ba}, \mathrm{Cr}, \mathrm{Co}, \mathrm{Ni}, \mathrm{Cu}, \mathrm{Fe}, \mathrm{Mn}$ and $\mathrm{Zn}$ were extracted according to the method of Soltanpour (1991). The qualitative minerals analysis of soils samples were measured using X-ray diffraction unit Philips PW-3710 with generator PW-1830, CO target tube and $\mathrm{Ni}$ filter at $40 \mathrm{kV}$ and $30 \mathrm{~mA}$.

\section{RESULTS AND DISCUSSION}

Table (1) shows some physical and chemical properties of Alluvial Toshka depression soils. Soil reaction $(\mathrm{pH})$ values in soils were ranged between 7.09 to 7.49 at depth 5-30 and $120-125 \mathrm{~cm}$ respectively. Soil reaction tends to be moderate. These results could be confirmed by these obtained by El- Aziz (2005) and Hassan (2006).

The $\mathrm{pH}$ values of Lake sediment samples along Lake Nasser are varying between minimum of 7.35 detected at Saara site in southern area to maximum value 8.05. The distribution of organic matter in sediment does not depend on particles size but it depends on the environmental condition as temperature, dissolved oxygen and pH values (Mohamed and Mostafa 2015). In arid regions, salt accumulation may occur in depressional areas. Maximum of electrical conductivity.

(EC dS.m ${ }^{-1}$ ) of soil was $5.48 \mathrm{dS} . \mathrm{m}^{-1}$ in surface layer at depth of $0-5 \mathrm{~cm}$. Minimum EC value was $2.45 \mathrm{dS} . \mathrm{m}^{-1}$ in subsurface layer at depth $5-30 \mathrm{~cm}$, the average of total soil salinity was $3.97 \mathrm{dS} . \mathrm{m}^{-1}$ with a regular distribution pattern with depth; if total salt concentration (ECse), exceeds $\left(2 \mathrm{dS} . \mathrm{m}^{-1}\right)$, they can be categorised as saltaffected (Abrol et al., 1988). Alluvial soils of Toshka Depression are classified under soil salinity class "slightly saline soils, many crops are restricted. Soluble ions in 
sediment soil were followed these order: $\mathrm{Na}>\mathrm{Mg} \geq \mathrm{Ca}>\mathrm{K}$, while the anion composition was dominated by $\mathrm{Cl}, \mathrm{SO}_{4}$ and $\mathrm{HCO}_{3}$ as $\mathrm{mEq} \cdot 100 \mathrm{~g}^{-1}$ and were followed the order: $\mathrm{Cl}>\mathrm{SO}_{4}>\mathrm{HCO}_{3}$, but $\mathrm{CO}_{3}$ was zero.

Table 1: Some physical and chemical properties of Alluvial Toshka depression soils.

\begin{tabular}{|c|c|c|c|c|c|}
\hline \multicolumn{6}{|c|}{ Depth cm } \\
\hline Character & $(0-5)$ & $(5-30)$ & $(30-75)$ & $(75-120)$ & $(120-125)$ \\
\hline Sand \% & 16.67 & 28.30 & 28.66 & 24.12 & 22.34 \\
\hline Silt\% & 47.22 & 39.23 & 3.24 & 13.92 & 61.18 \\
\hline Clay \% & 36.11 & 32.45 & 38.10 & 61.96 & 16.48 \\
\hline Texture class & $* \mathrm{SCL}$ & $* \mathrm{CL}$ & $* \mathrm{CL}$ & $* \mathrm{C}$ & $* \mathrm{SL}$ \\
\hline Saturation percentage (SP\%) & 40 & 45 & 60 & 35 & 35 \\
\hline CEC mEq.100g ${ }^{-1}$ & 7.10 & 7.09 & 7.15 & 7.23 & 7.47 \\
\hline EC ds.m ${ }^{-1}(1: 1)$ & 5.48 & 2.45 & 3.16 & 4.77 & 3.97 \\
\hline \multicolumn{6}{|l|}{ Soluble ions mEq.l- } \\
\hline $\mathbf{N a}$ & 21.8 & 7.2 & 16.1 & 26.8 & 16.5 \\
\hline $\mathbf{K}$ & 0.89 & 0.25 & 0.28 & 0.25 & 0.25 \\
\hline $\mathbf{C a}$ & 15.7 & 8.5 & 7.7 & 9.0 & 11.5 \\
\hline Mg & 16.5 & 8.6 & 7.7 & 11.6 & 11.5 \\
\hline $\mathrm{Cl}$ & 35.0 & 15.0 & 15.0 & 30.0 & 25.0 \\
\hline $\mathrm{HCO}_{3}$ & 10.27 & 8.16 & 7.24 & 6.33 & 9.52 \\
\hline $\mathrm{SO}_{4}$ & 13.2 & 5.4 & 16.1 & 12.5 & 11.6 \\
\hline Gypsum mEq. $^{-1}$ & 10.27 & 8.16 & 7.24 & 6.33 & 9.52 \\
\hline $\mathrm{CaCO}_{3} \%$ & 27.1 & 3.2 & 1.83 & 1.02 & 0.2 \\
\hline O.M\% & 7.8 & 1.2 & 0.42 & 0.48 & 0.38 \\
\hline pH (1:2.5) & 18.5 & 15.4 & 18.3 & 18.9 & 16.1 \\
\hline ESP\% & 6.9 & 0.8 & 6.5 & 7.9 & 5.8 \\
\hline
\end{tabular}

\begin{tabular}{|c|c|c|c|c|c|c|c|c|}
\hline & \multicolumn{4}{|c|}{ Available Macronutrients as (mg.kg ${ }^{-1}$ ) } & \multirow{2}{*}{\multicolumn{3}{|c|}{ *Optimum as (mg.kg-1) }} \\
\hline & & \multicolumn{4}{|l|}{ Depth cm } & & & \\
\hline & $(0-5)$ & $(5-30)$ & $(30-75)$ & $(75-120)$ & $(120-125)$ & Poor & Moderate & adequate \\
\hline $\mathbf{N}$ & 65.8 & 13.6 & 12.2 & 10.4 & 8.4 & $5-15$ & $30-40$ & $30-40$ \\
\hline $\mathbf{P}$ & 3.1 & 0.38 & 1.8 & 1.10 & 2.4 & $3-8$ & $8-14$ & 14-20 \\
\hline $\mathbf{K}$ & 187 & 145 & 127 & 95 & 79 & $85-150$ & $150-250$ & $250-450$ \\
\hline
\end{tabular}

\begin{tabular}{|c|c|c|c|c|c|c|c|}
\hline & \multicolumn{4}{|c|}{$\begin{array}{c}\text { Total Heavy metals as }\left(\mathrm{mg}^{\mathrm{kg}}{ }^{-1}\right) \\
\text { Depth cm }\end{array}$} & \multirow[b]{2}{*}{$(120-125)$} & \multirow[b]{2}{*}{ ***Normal level } & \multirow[b]{2}{*}{ *Critical level } \\
\hline & $(0-5)$ & $(5-30)$ & $(30-75)$ & $(75-120)$ & & & \\
\hline $\mathbf{F e}$ & 371.1 & 6194.5 & 8382.2 & 4884.5 & 37835.8 & & \\
\hline $\mathbf{B a}$ & 66.9 & 28.3 & 32.3 & 21.3 & 36.6 & & \\
\hline $\mathrm{Cr}$ & 26.2 & 20.9 & 20.9 & 80.7 & 18.3 & $75-100$ & $75-100$ \\
\hline Co & 6.7 & 7.6 & 13.3 & 6.8 & 25.9 & $0.5-65$ & $3-8$ \\
\hline $\mathbf{C u}$ & 458.5 & 227.3 & 383.8 & 371.1 & 367.0 & $2-250$ & $60-125$ \\
\hline Mn & 2891.5 & 788.2 & 670.9 & 498.7 & 1055.9 & $20-10000$ & $1500-3000$ \\
\hline $\mathbf{N i}$ & 27.1 & 24.6 & 33.9 & 23.3 & 64.7 & $2-750$ & 100 \\
\hline $\mathbf{Z n}$ & 219.4 & 82.4 & 111.0 & 78.4 & 212.4 & $1-900$ & $70-400$ \\
\hline
\end{tabular}

\begin{tabular}{|c|c|c|c|c|c|c|c|c|}
\hline & & & \multicolumn{3}{|c|}{$\begin{array}{c}\text { Total Heavy metals as (mg.kg-1) } \\
\text { Depth cm }\end{array}$} & \multirow[b]{2}{*}{ Poor } & \multirow[b]{2}{*}{ Moderate } & \multirow[b]{2}{*}{ adequate } \\
\hline & & & $(30-75)$ & $(75-120)$ & $(120-125)$ & & & \\
\hline Ba & $(0-5)$ & $(5-30)$ & 2.6 & 1.8 & 63.8 & & & \\
\hline $\mathrm{Cr}$ & 7.2 & 5.2 & 17.6 & 13.0 & 31.2 & & & \\
\hline Co & 9.8 & 22.8 & $<0.003$ & $<0.003$ & $<0.003$ & & & \\
\hline $\mathbf{C u}$ & 49.0 & $<0.003$ & 108.0 & 155.0 & 61.0 & $<0.3$ & $0.9-1.2$ & 1.3-2.5 \\
\hline $\mathbf{F e}$ & 121.8 & 36.8 & 37.6 & 30.2 & 239.0 & $0-5$ & 11-16 & $17-35$ \\
\hline Mn & 3318.0 & 201.4 & 92.0 & 110.4 & 66.0 & & & \\
\hline $\mathbf{N i}$ & 970.0 & 95. & 6.4 & 7.4 & 13.0 & $0-4$ & $9-12$ & 13-30 \\
\hline $\mathbf{Z n}$ & 59.8 & 27.6 & 141.0 & 176.6 & 0.4 & $<0.5$ & 1.1-3 & $3.1-6$ \\
\hline
\end{tabular}

Physical and chemical conditions of the soil will change due to accumulation of toxic specific ions $\mathrm{Na}, \mathrm{Mg}$ and $\mathrm{Cl}$ in soil solution that will raise the osmotic potential of the soil solution FAO (1988). The increase in calcium concentration in solution leads usually to a drop in potassium uptake by plants. Similarly, the increase in calcium concentration could lead to a drop in magnesium uptake. In general, the 
relationship between $\mathrm{Ca}, \mathrm{Mg}$ and $\mathrm{K}$ is related to texture, organic matter and the type of clay in the soil. According to data in Table (1), the soil texture class was recorded silty clay loam in surface layer at depth $0-5 \mathrm{~cm}$, clay loam at subsurface layer at depth $5-75 \mathrm{~cm}$, clay at depth $75-120 \mathrm{~cm}$ and silt loam at depth $120-125 \mathrm{~cm}$ sandy soils. Movement of clay in soil profile increased with increasing precipitation. In arid regions, salt accumulation may occur in depressional areas. Accumulation of organic matter extends deeper into the surface soil. Clay minerals are moved by water from near the soil surface to deeper in the developing profile. Sand fraction ranged from a maximum value of $30.32 \%$ at Saara site in southern area of the lake and it has a minimum value of $8.42 \%$ at Abrium site. As well as, the silt fraction varied between 9.91\% at Abrium and $22.62 \%$ at Arkeen. Also, the clay fraction in Lake Nasser sediment was varied between the maximum value $81.67 \%$ as compared with the minimum of 50.68\% in northern part of lake Nasser. (Mohamed and Mostafa 2015). Gypsum distributes with a regular pattern from the surface layer at depth 0-5 to subsurface layer at $120 \mathrm{~cm}$, then gypsum accumulates at depth $125 \mathrm{~cm}$ with an average of $8.30 \mathrm{mEq} . \mathrm{l}^{-1}$. Gypsum content in Toshka area is differed from 3.0 to $81.0 \mathrm{gk.g}$. in

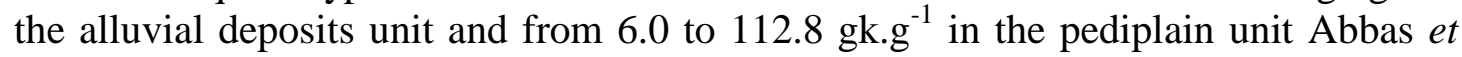
al., (2010); accumulates below the first appearance of secondary $\mathrm{CaCO}_{3}$ because gypsum is more soluble act as barriers to clay movement. Gypsum may control the movement of fines in two different ways: First, gypsum is much more soluble than $\mathrm{CaCO}_{3}$; thus it flocculates clay particles more effectively than $\mathrm{CaCO}_{3}$ and can prevent clay from being translocated into the profile. Second, if enough gypsum accumulates, the soil horizon may be plugged, and clay particles physically cannot pass through it Marith 1987; FAO 1988). Gypsum is precipitated and accumulates when the electric conductivity is less than $60 \mathrm{mS} . \mathrm{cm}^{-1}$. As the gypsum content increases, the calcium carbonate content tends to decrease and vice-versa. In arid and semi-arid areas gypsum is dissolved in the wet season and tends to be precipitated when the soil is dry. 3. Subdivision according to the thickness of the gypsic horizon: $<40 \mathrm{~cm}$ slightly thick 40-100 $\mathrm{cm}$ moderately thick $>100 \mathrm{~cm}$ thick 4 . Subdivision according to the size of gypsiferous accumulation: $0.1 \mathrm{~mm}$ microcrystalline $0.1-1.0 \mathrm{~mm}$ micro-mesocrystalline 1.0-10 mm mesocrystalline $10-100 \mathrm{~mm}$ macro crystalline. $\mathrm{CaCO}_{3}$ content was $3.22,1.83,1.02$ and $0.2 \%$ at depth $(5-30,30-75,75-120$ and 120-125) cm respectively. With a regular distribution pattern with Maximum depth value of Calcium carbonate content $(27.12 \%)$ was observed seams holding in thin surface layer in soil sediments adjacent Toshka Depression. Calcium carbonate content varied from 2.6 to 142.0 gk.g ${ }^{-1}$ in the alluvial deposits in Toshka area Abbas et al., 2010). Leaching of soluble materials like $\mathrm{CaCO}_{3}$ increases with increasing precipitation but lowering precipitation is the characteristics of arid regions. The percentage of total carbonate in Lake Nasser sediment ranged between $2.93 \%$ and $6.08 \%$. The concentration of carbonate in lake sediment depends on the nature of sediment silt, density of macro, microorganisms, mollusca and flood effect (Mohamed and Mostafa, 2015). Calcium carbonate dissolution rates from sediments are controlled by solubility and external processes that control the saturation state of the surrounding fluids. Two distinctly different geological can be recognized, first carbonate deposited by action of evaporation of surface water of the lake as follow: $2 \mathrm{HCO}_{3} \longleftrightarrow 2 \mathrm{H}^{+}+2 \mathrm{CO}_{3}$. Secondary carbonate sedimentation in fresh water in humid regions quantitive based on carbonate content boundary as dominate mineral (calcite) (Hales, 1995). Organic matter $(\mathrm{OM})$ content at surface layer at depth $0-5 \mathrm{~cm}$ of alluvial sediment soils was recorded $7.8 \%(\mathrm{OM})$ content which, represents very reach, and that may be due to disintegration of organisms inhabiting the lake (cyanobacterial mats, macro- and 
microphytes, phytoplankton, zooplankton, benthic organisms or feces from aquatic or terrestrial organisms (Kelts, 1988). Minimum OM content $0.38 \%$ was observed at depth $120-125 \mathrm{~cm}$ with an average of $2.06 \%$. OM\% deceased with a regular distribution pattern with depth. In the alluvial deposits unit, the value of organic matter content ranged from 0.4 to $9.7 \mathrm{gk} \cdot \mathrm{g}^{-1}$ (Abbas et al., 2010). Organic matter in sediments does not clearly depend on particle size but it predominantly depends on the environmental condition as temperature, dissolved oxygen and $\mathrm{pH}$ value and nature of formation of organic matter content that ranged between 3.36\% and $9.48 \%$ in Lake Nasser sediment. The results show that the high organic area of North Lake attributed to low water current velocity (Mohamed and Mostafa, 2015). Soil organic matter can be found in the clay and silt fractions (Hassink, 1997). Generally in arid region lowering organic matter content in subsurface layer is due to higher temperature and lower moisture and scanty vegetation. (Khader and Hussien, 2003). Concerning the Cation Exchange Capacity (CEC); maximum value was recorded 22.7 mEq. $100 \mathrm{~g}^{-1}$ at depth $75-120 \mathrm{~cm}$ and the minimum value was $19.30 \mathrm{mEq} .100 \mathrm{~g}^{-1}$ at depth $120-125 \mathrm{~cm}$ with an average of $20.90 \mathrm{mEq} .100 \mathrm{~g}^{-1}$. CEC values in differed alluvial deposits was from 7.02 to $31 . \mathrm{mEq} .100 \mathrm{~g}^{-1}$ (Abbas et al., 2010). In general, cation exchange capacity increases with higher clay content, so that fine textured soils tend to have higher cation exchange capacity than coarse textured soils. Organic particles also adsorb nutrients (Mitra et al., 2005; Kayranli et al., 2010) and mineralogical composition, Caravaca, et al., (1999). Exchangeable sodium percentage (ESP \%) were ranged between 0.8 at depth $5-30 \mathrm{~cm}$ to 7.9 at depth $75-120 \mathrm{~cm}$. Finally, the variation in CEC and ESP \% among layers of the investigated soil may be due to the differences in mineralogical composition. Data in Table (1) reveal that the studied macro nutrients (N, P and K) of alluvial soil, according to FAO (2007) the highest value of nitrogen as nitrate (65.8) mg. $\mathrm{kg}^{-1}$ was observed in surface layer at depth of 0 $5 \mathrm{~cm}$, which represent adequate value while through soil profile from subsurface layer at depth 5-3 to the end of profile at depth $120-125 \mathrm{~cm}, \mathrm{~N}$ was decreased with soil depth in addition to $\mathrm{P}$ and $\mathrm{K}$. It can be concluded that investigated alluvial soil sediment suffers from a sever leak of available macronutrients NPK, that may be due to high temperature, texture class, lower moisture. All Egyptian soils are poor in their content of organic matter, total nitrogen and other nutritive elements. Data reveal that, the maximum total concentrations of $\mathrm{Ba}, \mathrm{Cu}, \mathrm{Mn}$ and $\mathrm{Zn}$ were found in surface layer at depth $0-5 \mathrm{~cm}$, recorded $66.9,4584,2891.5$, and $219.4 \mathrm{mg} . \mathrm{Kg}^{-1}$ respectively. Maximum $\mathrm{Cr}$ was recorded 80.7, while $\mathrm{Co}, \mathrm{Fe}$, and $\mathrm{Ni}$ were recorded 25.9, 37835.8 and 64.7 mg. $\mathrm{Kg}^{-1}$ at depths of $30-75$, and $120-125 \mathrm{~cm}$ respectively. But the minimum values of $\mathrm{Ba}, \mathrm{Cr}, \mathrm{Co}$, and $\mathrm{Cu}$, were recorded $21.3,18.3,6.7$ and $227.3 \mathrm{mg} \cdot \mathrm{Kg}^{-1}$ at depths of $120-$ $125,75-120,120-125$ and $5-30 \mathrm{~cm}$, respectively, while the minimum concentration of $\mathrm{Fe}, \mathrm{Mn}, \mathrm{Ni}$ and $\mathrm{Zn}$ were recorded 4884.5, 498.7, 23.3 and $78.4 \mathrm{mg} . \mathrm{Kg}^{-1}$ respectively and observed in subsurface layer at depth of $75-120 \mathrm{~cm}$. Data reveal that, the distribution of: $\mathrm{Ba}, \mathrm{Cr}, \mathrm{Co}, \mathrm{Cu}, \mathrm{Fe}, \mathrm{Mn}, \mathrm{Ni}$ and $\mathrm{Zn}$ from surface layer to the end depth of the studied soil profile at depth of zero to $125 \mathrm{~cm}$, were recorded; $37.1,34.9,12.1$, $361.5,13079.2,1181.1,34.7$ and $140.7 \mathrm{mg} . \mathrm{Kg}^{-1}$ with a standard deviation, 4213.5, 17.6, 25.9, 8.2, 83.7, 13913.2, 977.4, 17.3 and $69.7 \mathrm{mg} \mathrm{Kg}^{-1}$ respectively. On the other hand $\mathrm{Ni}$ and $\mathrm{Zn}$ were in critical levels while $\mathrm{Cu}$ and $\mathrm{Mn}$ were in Normal range. According to the permissible level of Alloway, (1995); Kabata-Pendias and Pendias (1992). As for the depth distribution of heavy metals in soil profiles, the maximum values of total $\mathrm{Fe}\left(37835.8 \mathrm{mg} \cdot \mathrm{kg}^{-1}\right)$ was accumulated at the end of soil profile at depth $120-125 \mathrm{~cm}$, more than four times those in surface horizon. The mobility of heavy metals could be influenced by soil properties, soil structure, and soil 
development. The mobility of heavy metals could be influenced by soil properties, soil structure, and soil development. (Tessier and Campbell, 1987). Heavy metals were not necessarily fixed permanently to soils, but they also took part in biogeochemical cycles; therefore, assessment of their distribution in soils was a key issue in many environmental studies. In alluvial soil sediments adjacent of Lake Nasser, the order of accumulation was $\mathrm{Fe}>\mathrm{Mn}>\mathrm{Cu}>\mathrm{Zn}$. Suspended sediments transported by the River were suggested to be one of the major sources for the heavy metals accumulation in the basal soils of this region; most of the metals $(\mathrm{Cr}, \mathrm{Ni}, \mathrm{Cu}$, and $\mathrm{Zn}$ ) were sourced from natural alluviation and sedimentation (Yuan et al., 2014). Total heavy metals in sediment soil were followed these order: $\mathrm{Fe}>\mathrm{Mn}>\mathrm{Cu}>\mathrm{Zn}>$ $\mathrm{Cr}>\mathrm{Ba}>\mathrm{Ni}>\mathrm{Co}$. Figure (2) shows that the maximum available heavy metals: $\mathrm{Ba}$, $\mathrm{Co}, \mathrm{Ni}, \mathrm{Fe}, \mathrm{Mn}$ and $\mathrm{Zn}$ were accumulated in surface layer at depth of $0-5 \mathrm{~cm}$ and recorded, 7.2, 49.0, 59.8, 3318.0, 970.0, and $179.8 \mathrm{mg} . \mathrm{kg}^{-1}$ respectively, with a standard deviation (SD) 2.7, 34.1, 23.1, 1399.6, 393.4 and $64.2 \mathrm{mg} . \mathrm{kg}^{-1}$, while $\mathrm{Cu}$ and Cr were recorded: 9.0, 31.2 and 155.0 in subsurface layer at depth of 30-75, 75-120 and $120-125 \mathrm{~cm}$, respectively, with an standard deviation (SD) $2.8,47.5$ and 8.5 mg.kg- ${ }^{-1}$. While minimum $\mathrm{Cr}$ was recorded 9.8 in surface layer at depth $\left.0-5 \mathrm{~cm}\right), \mathrm{Cu}$, $\mathrm{Zn}$, (were recorded 36.8, 27.6 in sudsurface layer at depth $5-30 \mathrm{~cm}$ ), $\mathrm{Ni}, \mathrm{Fe}$ (were recorded 6.4, 141.0 in sudsurface layer at depth $30-75 \mathrm{~cm}$ ) and $\mathrm{Ba}, \mathrm{Co}, \mathrm{Mn}$ (were recorded $0.4,0.8,66.0$ in the end of soil profile at depth $120-125 \mathrm{~cm}$ ). Also data reveal that the average of available heavy metals, $\mathrm{Ba}, \mathrm{Cr}, \mathrm{Co}, \mathrm{Ni}, \mathrm{Cu}, \mathrm{Fe}, \mathrm{Mn}$ and $\mathrm{Zn}$ were recorded 7.0, 18.9, 3.4, 24.9, 18.7, 96.5, 815.2, 266.8 and $67.8 \mathrm{mg} . \mathrm{kg}^{-1}$. Finally data reveal that the most total and available heavy metals were accumulated in surface layer of alluvial soil sediment profile at Toshka Depression.

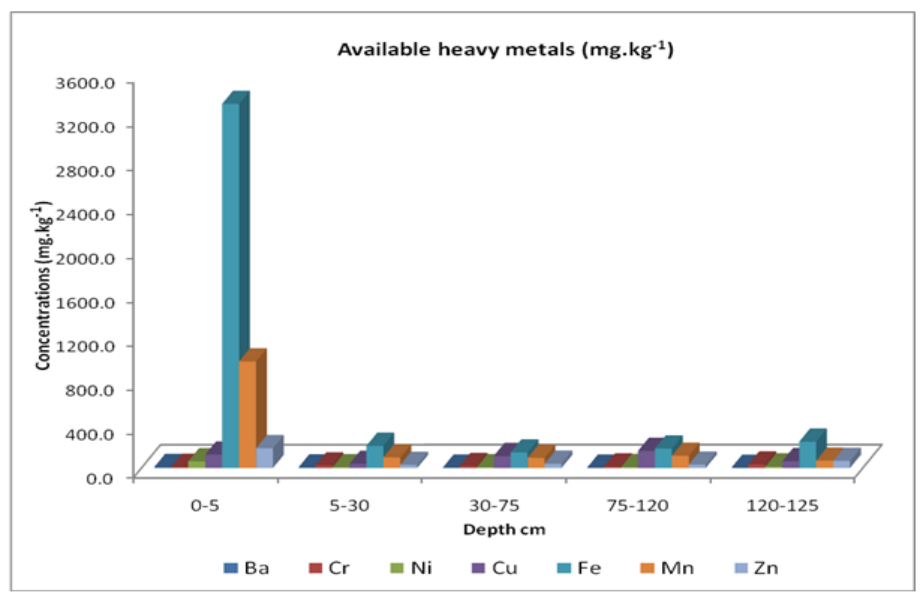

Fig. 2: Available heavy metals in alluvial soil sediment at Toshka Depression.

This may be due to that alluvial sediment soils are very reach in organic matter, due to disintegration of organisms inhabiting the lake (cyanobacterial mats, macro- and microphytes, phytoplankton, zooplankton, benthic organisms or feces from aquatic or terrestrial organisms (Kelts, 1988., Huacheng et al., 2013).

Data in Table (2) and illustrated in Figs. (3, 4, 5, 6 and7) showed that the X-ray patterns of the bulk alluvial soils sediment in Toshka soils Depression, at depths 0$125 \mathrm{~cm}$ dominate minerals are Illite, Vermiculite, Montmorillonite, Calcite, Magnetite, Kaolinite-1A, Hematite, Berlinite, Cronstedtite-1T, Cuprite, Fraipontite-1O, Gypsum, Bustamite, Wollastonite-1A, and Brushite (Melegy and El-Agami, 2004). They stated that the Nile alluvial soils in Bahtim district are composed mainly of montmorillonite 
ranges in abundance from $27 \%$ to $35 \%$, Kaolinite ranges from $29 \% 35.5 \%$ and Illite from $3 \%$ to $11 \%$.

Table 2: Identified minerals of alluvial soil sediment in Toshka Depression at depth of 0-125cm.

\begin{tabular}{|c|c|c|c|}
\hline Ref. Code & Chemical Formula & PDF Index Name & Mineral Name \\
\hline 00-029-1496 & K0.7 Al2 ( $\mathrm{Si}, \mathrm{Al}) 4 \mathrm{O10}(\mathrm{O} \mathrm{H}) 2$ & Potassium Aluminum Silicate Hydroxide & Illite-1M (NR) \\
\hline $00-060-0341$ & $\mathrm{Mg3}(\mathrm{Si}, \mathrm{Al}) 4 \mathrm{O10}(\mathrm{O} \mathrm{H}) 2 \cdot 4 \mathrm{H} 2 \mathrm{O}$ & $\begin{array}{c}\text { Magnesium Aluminum Silicate } \\
\text { Hydroxide Hydrate }\end{array}$ & Vermiculite \\
\hline 00-058-2010 & $\mathrm{Na} 0.3(\mathrm{Al}, \mathrm{Mg}) 2 \mathrm{Si} 4 \mathrm{O} 10(\mathrm{OH}) 2 \cdot \times \mathrm{H} 2 \mathrm{O}$ & $\begin{array}{c}\text { Sodium Aluminum Magnesium Silicate } \\
\text { Hydroxide Hydrate }\end{array}$ & Montmorillonite \\
\hline 00-005-0586 & $\mathrm{Ca} \mathrm{C} \mathrm{O3}$ & Calcium Carbonate & Calcite, syn \\
\hline 01-074-1909 & Fe3 O4 & Iron Oxide & Magnetite, syn \\
\hline 00-058-2001 & Al2 Si2 O5 ( O H )4 & Aluminum Silicate Hydroxide & Kaolinite-1A \\
\hline 00-001-1053 & Fe2 O3 & Iron Oxide & Hematite \\
\hline 00-036-0432 & Ca S O4 $\cdot 2$ H2 O & Calcium Sulfate Hydrate & Gypsum \\
\hline $04-009-5763$ & Al (P O4) & Aluminum Phosphate & Berlinite \\
\hline 04-013-2662 & Fe3 Si2 O5 (O H)4 & Iron Silicate Hydroxide & Cronstedtite-1T \\
\hline 04-003-6433 & $\mathrm{Cu} 2 \mathrm{O}$ & Copper Oxide & Cuprite \\
\hline 00-034-0782 & $(\mathrm{Zn}, \mathrm{Al}, \mathrm{Cu}) 3(\mathrm{Si}, \mathrm{Al}) 2 \mathrm{O5}(\mathrm{O} \mathrm{H}) 4$ & $\begin{array}{c}\text { Copper Zinc Aluminum Silicate } \\
\text { Hydroxide }\end{array}$ & Fraipontite-10 \\
\hline 00-044-1455 & $\mathrm{Ca}(\mathrm{Mn}+2, \mathrm{Ca}) \mathrm{Si} 2 \mathrm{O6}$ & Calcium Manganese Silicate & Bustamite, calcian \\
\hline $00-027-1056$ & $(\mathrm{Ca}, \mathrm{Fe}) \mathrm{Si} \mathrm{O3}$ & Calcium Iron Silicate & $\begin{array}{c}\text { Wollastonite-1A, } \\
\text { ferroan }\end{array}$ \\
\hline 00-011-0293 & Ca P O3 ( O H ) 2 H2 O & $\begin{array}{c}\text { Calcium Phosphate Hydroxide } \\
\text { Hydrate }\end{array}$ & Brushite \\
\hline
\end{tabular}

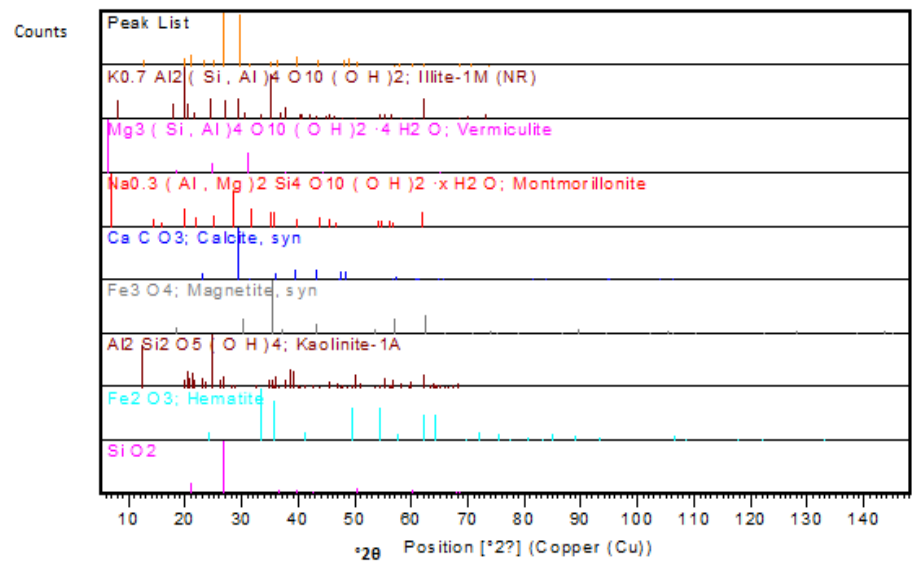

Fig. 3: Identified minerals of alluvial soil sediment in Toshka Depression at Lake Nasser by X-ray diffraction at depth of $0-5 \mathrm{~cm}$.

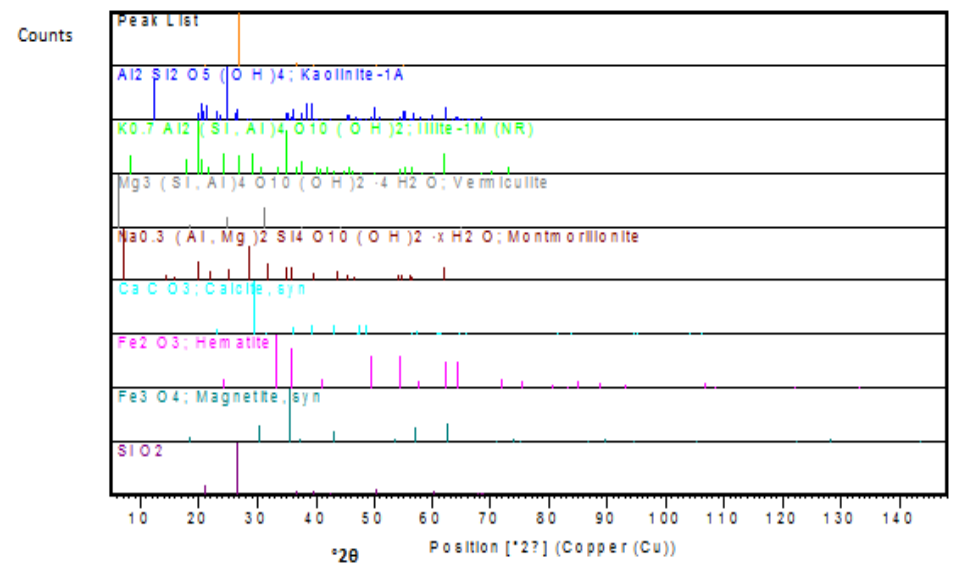

Fig. 4: Identified minerals of alluvial soil sediment in Toshka Depression at Lake Nasser by X-ray diffraction at depth of 5-30-cm. 


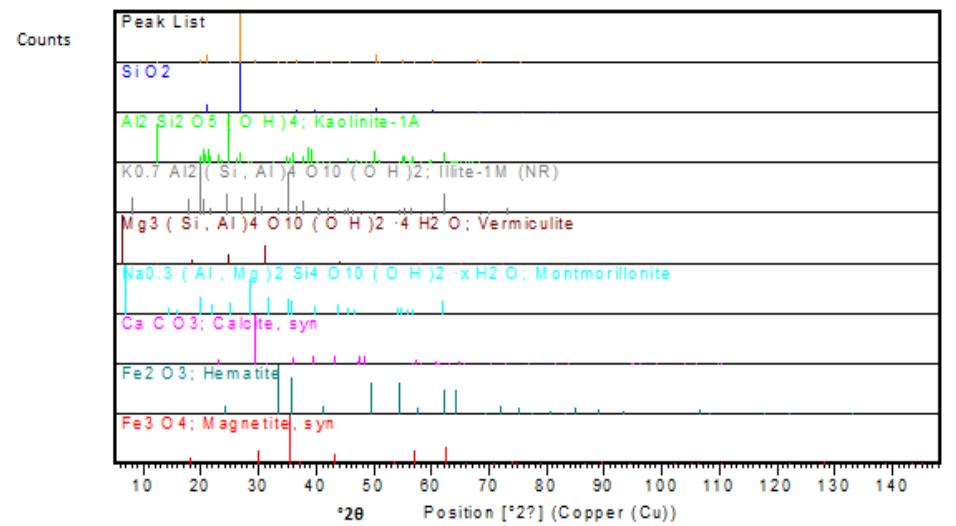

Fig. 5: Identified minerals of alluvial soil sediment in Toshka Depression at Lake Nasser by X-ray diffraction at depth of 30-75-cm.

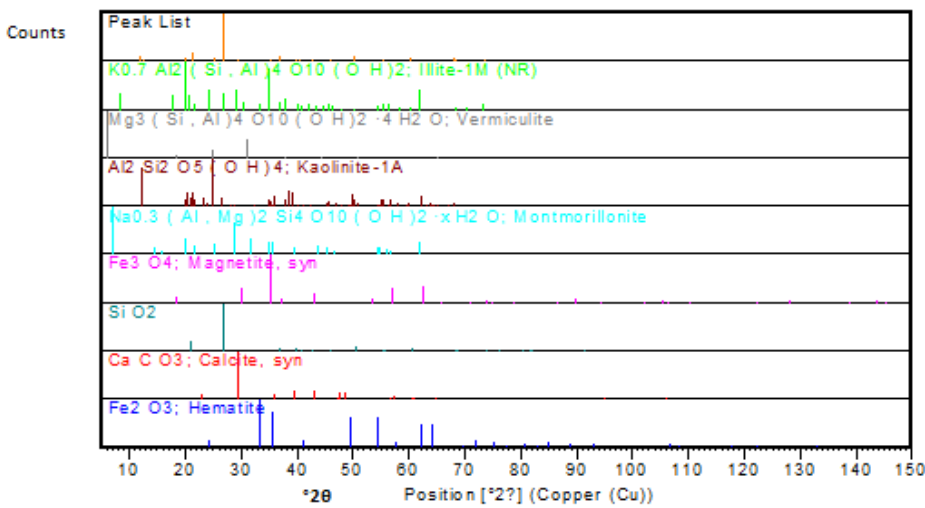

Fig. 6: Identified minerals of alluvial soil sediment in Toshka Depression at Lake Nasser by X-ray diffraction at depth of $75-120 \mathrm{~cm}$.

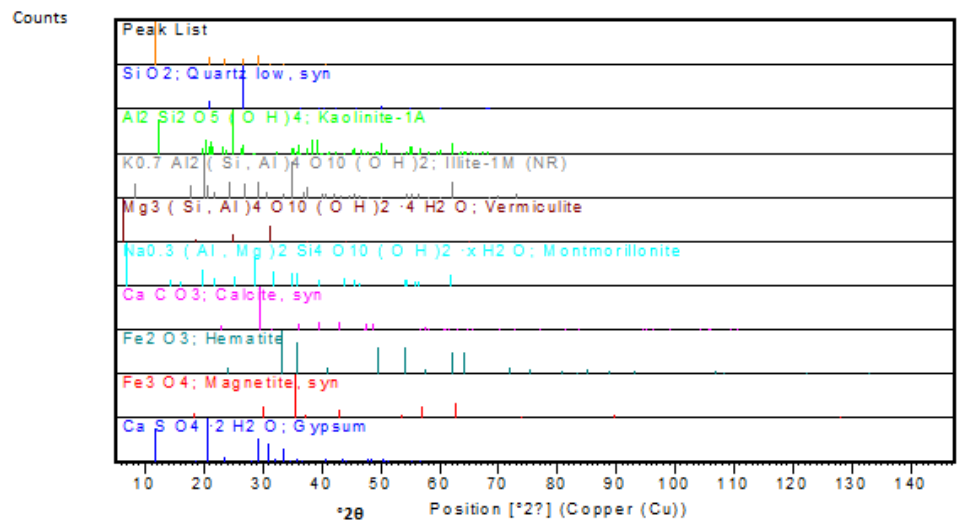

Fig. 7: Identified minerals of alluvial soil sediment in Toshka Depression at Lake Nasser by X-ray diffraction at depth of $120-125 \mathrm{~cm}$.

\section{CONCLUSIONS}

From the previous results it can be concluded that, land suitability classes of the investigated alluvial soil sediment at Toshka Depression are defined according to the values of suitability index ( $\mathrm{Si}$ ) for cultivation of certain crops, which were suggested by Mekhail (2003) as moderately suitable (S2). X-ray patterns of the bulk alluvial soils sediment in Toshka soils Depression, show that the dominate minerals are: Illite, 
Vermiculite, Montmorillonite, Kaolinite-1A, Magnetite, Hematite, Berlinite, Cronstedtite-1T, Cuprite, Fraipontite-1O, Calcite, Gypsum, Bustamite, Wollastonite1A, and Brushite. High organic matter content in surface layer and minerals in subsurface layer of Alluvial soils sediment in Toshka soils Depression considered a treasure for agricultural sustainable or for possible use in land reclamation in south valley, Egypt.

\section{REFERENCES}

Abbas, H . H; El-Husseiny, O. H; Mohamed, M.K. and Abuzaid, A.S. (2010). Land Capability and Suitability of some Soils in Toshka Area, Southwestern, Egypt. Annals of Agric. Sci., Moshtohor, 48(1): So. 1-12.

Abdelhamid, El. (2013). Characterization of Soil Clay Minerals of the River Nile Sediments, Sohag Region, Egypt: Decomposition of X-Ray Diffraction Patterns. Journal of Earth Science and Engineering 1-13.

Abrol, I . P.; Yadav, J.S.P. and Massoud, F.I. (1988). Salt Affected Soils and Their Management, FAO Soils Bulletin, vol. 39. Italy, Rome, 93 pp.

Abu Seif, E.S. and El-Shater, A . A. (2010). Engineering Aspects and Associated Problems of Flood Plain Deposits in Sohag Governorate, Upper Egypt, Journal of American Science, 6 (12) 1614-1623.

Alloway B. J. (1995). Heavy Metals in Soils. Blackie Academic and Professional, 2nd ed. Lomdon, Uk.

Baruah, T. C. and Barthakur, H. P. (1997). A text book of soil analysis. Vikas Publishing, PVTLTD, New Delhi.

Black, C. A. (1982). Methods of Soil Analysis. Part 2, Chemical and Microbiological Properties. Amere., Soc. Agron. Inc. Publisher, USA.

Caravaca, F.; Lax, A. and Albaladejo, J. (1999). Organic Matter, Nutrient Contents and cation exchange capacity in fine fractions from semiarid Calcareous Soils. ELSEVIER. Geoderma, 93: 161-176.

El-Aziz, S. H. (2005). Effect of Removing Free Ions Oxides on Cation Exchange Capacity of Some Soils of Southern Valleys of Egypt. Assiut J. of Agric., Scie, 36(4): 115-124.

Essa, Mahmoud, A.; Farragallah, M and El-Ameen, A. (2006). Clay Minerals and Their Interactions with Heavy Metals and Microbes of Soils Irrigated by Various Water Resources at Assiut, Egypt. Ass. Univ. Bull. Environ. Res., 9:(2).

FAO, (1988). Management of Gypsiferous Soils. Rome, Food and Agriculture Organization, Rom, Italy. No.(62).

FAO, (2007). Methods of Analysis for Soils of Arid and Semi-Arid Regions. Food and Agriculture Organization, Rom, Italy.

Fassieh, K. M. and Zaki, M. A.(2013). A Water Management Model for Toshka Depression. Journal of Applied Mathematics. Volume 2014, Article ID 731846, 10 Pages. http:// dx. Dioorg/10.1155/2014/731846.

Fayos, C.; Boix; Nadeu, E. Quiñonero, J. M.; Martínez -Mena; Almagro, M. and de Vente .J. (2015). Sediment Flow Paths and Associated Organic Carbon Dynamics Across a Mediterranean Catchment. Hydrol. Earth Syst. Sci.

Hales, B., (1995). Calcite Dissolution in Sediments of Ontong-Java Plateau. In Situ Measurement of Pore Water O and pH. Global Biogeochem. Cycles, 5:529-543. 
Hanna, F. (2000). Pedological Studies Development in Egypt During the last 50 Years (1950-2000)". Egyptian Soil Science Society (ESSS)-Golden Jubilee Congress 1950- 2000, Oct., 23-25.

Hassan, Y.K. (2006). Land Suitability Classification of Some Soils of Toshka Area, South Egypt. M.Sc. Thesis, Fac. of Agric.,Cairo Univ., Egypt.

Hassink, J., (1997). The capacity of soils to preserve organic C and $\mathrm{N}$ by their Association With Clay and Silt Particles. Plant and Soil, 191: 77-87.

Huacheng, Xu.; Guanghui, Yu.; Liuyan, Y. and Helong, J. (2013). Combination of two-Dimensional Correlation Spectroscopy and Parallel Factor Analysis to Characterize The Binding of Heavy Metals With DOM IN Lake Sediments. Journal of Hazardous Materials., 263:412-421.

Kabata-Pendias, A. and Pendias, H. (1992). Trace Elements in Soils and Plants. 2nd ed. CRC Press, Boca Raton, FL.

Kayranli, B; Scholz, M; Mustafa, A. and Hedmark, A. (2010). Carbon Storage and Fluxes Within Fresh Water Wetlands: a Critical Review. Wetlands, 30:111-124.

Kelts, K. (1988). Environments of Deposition of Lacustrine Source Rocks: an Introduction. Geological Society Special Publication, 40: 3-26.

Khader, M.Y. and Hussien,T.M.(2003). Soil and water suitability for sustainable Agricultural Development in South Valley (Toshka Area), Egypt J. Soil Sci., 43(2): 223-242.

Klute, A. (1986). Methods of Soil Analysis. Part 1.Physical and Mineralogical Methods, 2ed, ed., Amer. Soc. Agron., Monograph no.9, Madison, Wisconsin, USA.

Little Join, D.; Egila, J. N; Gosland, R. M.; Kunwar, U.K. and Smith, C. (1991). Graphitefurnace analysis. Analyt. Chim. Acta., V 250.

Maher, K. (2012). 10 Proposed Projects for Land Reform and Power Generation To Sustain the Life of the People of Egypt. http:// miktechnology wordpress.com/201112/21/10- Proposed Projects to save the nile delta and reclaim-2-million acres of Egypt desert. MIK Technology, USA.

Marith, C. R. (1987). Gypsic Soils on the Kane Alluvial Fans, Soil Chronosequences in the Western United States.

Mekhael, S. K. (2003). Land and water resources potentiality for agriculture use in some areas, South Egypt (Toshka). Ph.D. Thesis, Fac. of Agric., Cairo, Univ., Egypt.

Melegy, A. and El-Agami, N.L. (2004). Factors Controlling the Chemistry and Mineralogy of Selected Soil Type of the Czech Republic and Egypt, Bulletin of Geosciences 79 (1): 71-79.

Mitra, S.; Wassmann, R. and Vlek, P.LG. (2005). An Appraisal of Global Wetland Area and its Organic Carbon Stock. Curr Sci., 88:25-35.

Mohamed, E.F.; Toufeek and Mostafa and Koriem, A. (2015). Studies of the Factors Affecting the Distribution of Some Metals in Nasser Lake Sediment, Egypt. World Journal of Fish and Marine Sciences 7(4): 307-312.

Page, A. L.; Miller, R. H and Keeny, D. R. (1982). Methods of Soil Analysis. Part $\Pi$ Chemical and Microbiological Properties ( $2^{\text {nd }}$ ed.) Amer. Soc. Agron. Monograph no. 9 Madison, Wisconsin, USA.

*Sadek, S. A. and Sawy, S. (1989). Effect of Using Sewage Water in Irrigation for Different Long Periods on some Physical and Chemical Properties of Soils in El-Gabal El-Asfar farm in Egypt. Fayoum. J. Agric. Res. Dev., 3: 14-19.

Soltanpour, P.N. (1991). Determination of Nutrient Availability Element Toxicity by AB-DTPA. Soil Test and ICPS Adv. Soil Sci., (16): 165- 190. 
Tessier, A and Campbell, PGC (1987). Partitioning of Trace Metals in Sediments: Relationships with Bioavailability. Hydrobiologia 149:43-52.

Yahia, H. M. and Sebaee, E.S. ( 2012). Bioaccumulation of Heavy Metals in Water, Sediments and Fish (Oreochromis niloticus and Clarias anguillaris) in Rosetta Branch of River Nile, Egypt. African J. Biotech., 11(77):14204-14216.

Yuan, Li; Haibo, Zhang. Xiaobing, Chen. Chen; Yongming, Luo. Tu. and Christieetal. P. (2014). Distribution of Heavy Metals in Soils of the Yellow River Delta: Concentrations in Different Soil Horizons and Source Identification. J. Soils Sediments14:1158-1168.

\section{ARABIC SUMMARY}

$$
\begin{aligned}
& \text { دراسة بعض خصائص الاراضي الرسوبية في منخفض توشكي- مصر } \\
& \text { محمد محمود شريف } \\
& \text { مجمع البحوث و الدر اسات المائبة بأبو سمبل ووحدة الأستشار ات و والمعلومات لمدئ للمياه و الزر اعة بجنوب الو ادي } \\
& \text { بتوشكي - المركز القومى لبحوث المياه. }
\end{aligned}
$$

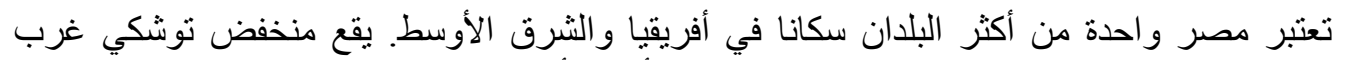

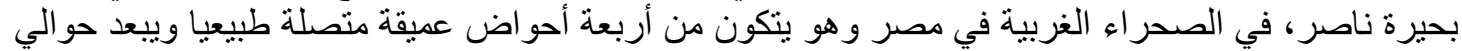

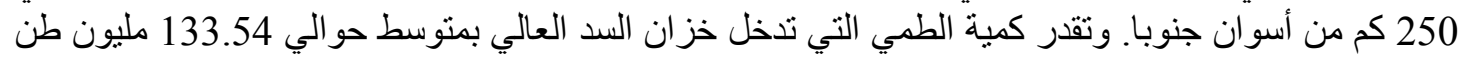

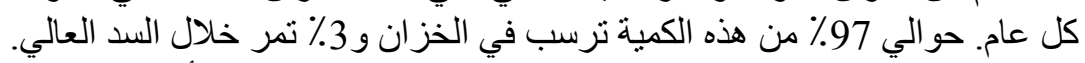

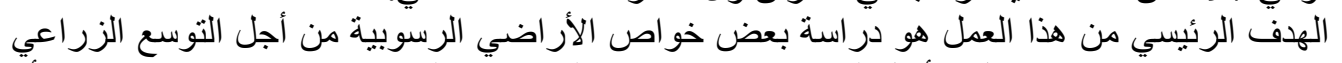

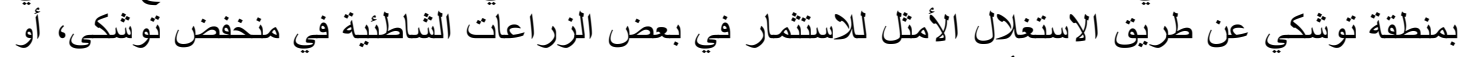

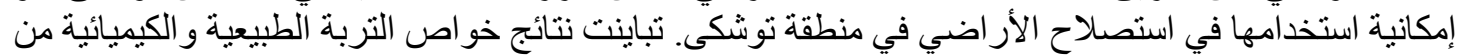

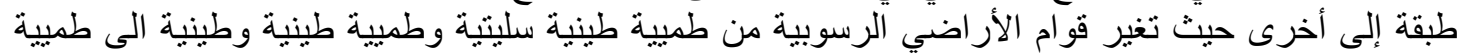

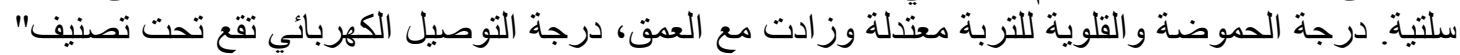

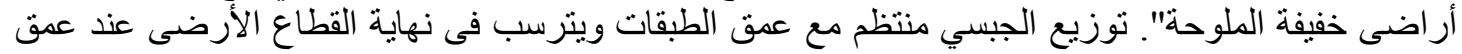

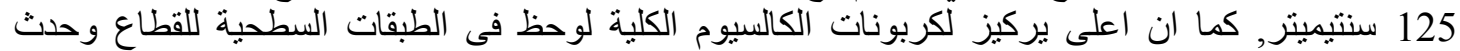

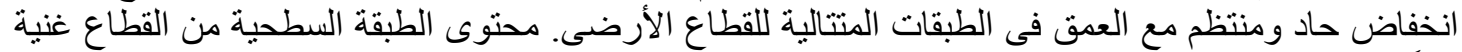

